\title{
Pyogenic abscesses in the myelodysplastic syndrome
}

\author{
P J Williamson, D G Oscier, G J Mufti, T J Hamblin
}

Unexplained pyogenic abscesses in the elderly should draw attention to the possibility of the myelodysplastic syndrome, which is greatly underdiagnosed

\section{Department of}

Haematology, Royal

Victoria Hospital,

Bournemouth BH1 4JG

P J Williamson, MRCP, senior registrar

D G Oscier, MRCPATH, consultant

G J Mufti, MrCPATH, leukaemia research fellow

T J Hamblin, FRCP, professor of immunohaematologv

Correspondence to: Dr Williamson.

Br.Med f 1989;299:375-6
The myelodysplastic syndromes are a group of primary blood disorders, occurring mainly in elderly people, that are united by characteristic morphological abnormalities of blood and bone marrow cells.' In most cases a hypercellular bone marrow, often with increased numbers of blast cells, is associated with pancytopenia in the peripheral blood. The diagnosis is sometimes difficult to make, especially when the blood count is nearly normal. As a consequence the syndrome is apparently much commoner in parts of the United Kingdom where haematologists have an interest in it.' A prevalence of 1 in 500 in patients over the age of 55 has been suggested.

Infections are common and are responsible for about a third of deaths and are a frequent cause of morbidity. ${ }^{+}$The granulocyte count is an important prognostic indicator of the myelodysplastic syndrome. ${ }^{+}$ Abnormalities of granulocyte function are also common, ${ }^{5}$ but their contribution to the increased risk of infection has not been determined.

We report on seven patients with the myelodysplastic syndrome who developed large abscesses. None had severe neutropenia when the abscesses developed, and all presented problems in diagnosis.

\section{Case reports}

The table gives clinical details and results of laboratory tests for the seven patients. The presentation and clinical course were different depending on whether the abscess was deep or superficial.

The patients in cases 1-3 presented with fever of unknown origin, and abdominal scans showed retroperitoneal abscesses. The patients in cases 4-7 presented with local pain and swelling, but the swellings were not hot and tender, nor was there major systemic illness. Only two of the patients had a neutrophilia, although in all cases the neutrophil count was higher than when the patient was free of infection. In all of the patients large quantities of pus were drained from the abscess. Staphylococcus aureus was cultured on four occasions, Escherichia coli on three, and Streptococcus faecalis on one. The six patients who were treated with simple drainage and antibiotics made uneventful recoveries. One patient (case 5) was treated by wide excision of the necrotic area. The wound never granulated satisfactorily, and the patient died of uncontrolled sepsis despite taking antibiotics.

The following case reports are examples of the two types of presentation and clinical course.

\section{CASE 1}

A 62 year old man was admitted to hospital with a three week history of malaise, fever, and dysuria. Four years previously chronic myelomonocytic leukaemia, a subtype of myelodysplastic syndrome, had been diagnosed and treated with etoposide and razoxane. When examined he had a temperature of $38^{\circ} \mathrm{C}$ and a mass was felt in the left loin. The results of investigations showed that haemoglobin concentration was $118 \mathrm{~g} / \mathrm{l}$, white cell count $14 \cdot 4 \times 10 \%$ (neutrophils $53 \%$, lymphocytes $3 \%$, monocytes $37 \%$, eosinophils $5 \%$, basophils $2 \%$ ), and platelet count $173 \times 10^{4} / 1$. The neutrophils were hypogranular, and occasional Pelger forms were seen. The bone marrow was hypercellular with trilineage dysplasia and $1 \%$ blast cells. On a scoring system for the severity of the myelodysplastic syndrome (modified Bournemouth score ${ }^{6}$ ) he scored 1 out of 4 . The results of liver function tests and serum urea, electrolyte, and immunoglobulin concentrations were normal. Computed tomography showed a large perinephric abscess. Staph aureus was cultured from a needle aspirate of the renal mass and from his urine.

$\mathrm{He}$ was treated by draining several hundred $\mathrm{ml}$ of pus through a percutaneous tube and with intravenous flucloxacillin. The pus contained abundant neutrophils. He made an uneventful recover and remained well until two years later, when he died a ter his disease progressed to acute myelomonocytic leu aemia.

\section{CASE 4}

An 86 year old woman presented with a five week history of increasing shortness of breath and pain in her left hip. Her previous medical history had been

Clinical details of seven patients with myelodysplastic syndrome

\begin{tabular}{|c|c|c|c|c|c|c|c|}
\hline Case No: & 1 & 2 & 3 & 4 & 5 & 6 & 7 \\
\hline Age (years)/sex & 62.11 & $70 \mathrm{~F}$ & $85 \mathrm{~F}$ & $86 \mathrm{~F}$ & $61 \mathrm{~F}$ & $86 M$ & $80 \mathrm{~F}$ \\
\hline History of myelodysplastic syndrome & & & & & & & \\
\hline (months) & 45 & 70 & 6 & nil & 47 & 16 & nil \\
\hline Diagnosis & $\begin{array}{l}\text { Chronic } \\
\text { myelomonocytic } \\
\text { leukaemia }\end{array}$ & $\begin{array}{l}\text { Refractory anaemia } \\
\text { with excess blast } \\
\text { cells }\end{array}$ & Refractory anaemia & Refractory anaemia & $\begin{array}{l}\text { Refractory anaemia } \\
\text { with excess blast } \\
\text { cells }\end{array}$ & Refractory anaemia & $\begin{array}{l}\text { Chronic } \\
\text { myclomonocytic } \\
\text { leukacmia }\end{array}$ \\
\hline Modified Bournemouth score" & 1 & 4 & 2 & 2 & 3 & 3 & 1 \\
\hline Presentation & $\begin{array}{l}\text { Malaise, } \\
\text { temperature } \\
38^{\circ} \mathrm{C} \text {, dysuria }\end{array}$ & $\begin{array}{l}\text { Malaise, } \\
\text { temperature } \\
37.5 C \text {, abdominal } \\
\text { pain }\end{array}$ & $\begin{array}{l}\text { Malaise, } \\
\text { temperature } \\
38 \cdot 5 \mathrm{C} \text {, abdominal } \\
\text { pain }\end{array}$ & $\begin{array}{l}\text { Hip pain, } \\
\text { temperature } \\
\quad 37.7 \mathrm{C}\end{array}$ & $\begin{array}{l}\text { Buttock pain, } \\
\text { temperature } \\
38.5 \mathrm{C}\end{array}$ & $\begin{array}{l}\text { Thigh pain, } \\
\text { temperature } \\
36.7 \mathrm{C}\end{array}$ & $\begin{array}{l}\text { Abdominal pain, } \\
\text { temperature } \\
37 \cdot 0)^{\circ}\end{array}$ \\
\hline $\begin{array}{l}\text { Site of abscess } \\
\text { Neutrophil count } \\
\left(\times 10^{\circ} / 1\right)\end{array}$ & Perinephric & Perinephric & Paravertebral & Thigh & Buttock & Thigh & Rectus sheath \\
\hline On admission & $7 \cdot 7$ & 1.9 & $16 \cdot 2$ & $6 \cdot 6$ & $1 \cdot 7$ & $2 \cdot 8$ & $13 \cdot 3$ \\
\hline When well & $5 \cdot 4$ & 0.9 & $2 \cdot 4$ & $5 \cdot 4$ & $0 \cdot 4$ & 1.5 & $6 \cdot 3$ \\
\hline Organism & Sluph aureus & E coli & E coli & Staph aureus & Staph aureus, E coli & Staph aureus & Strep faccalis \\
\hline Treatment & $\begin{array}{l}\text { Incision, drainage, } \\
\text { antibiotics }\end{array}$ & $\begin{array}{l}\text { Incision, drainage, } \\
\text { antibiotics }\end{array}$ & $\begin{array}{l}\text { Incision, drainage, } \\
\text { antibiotics }\end{array}$ & $\begin{array}{l}\text { Incision, drainage, } \\
\text { antibiotics }\end{array}$ & $\begin{array}{l}\text { Wide excision, } \\
\text { antibiotics }\end{array}$ & $\begin{array}{l}\text { Incision, drainage, } \\
\text { antibiotics }\end{array}$ & $\begin{array}{l}\text { Incision, drainage, } \\
\text { antibiotics }\end{array}$ \\
\hline Outcome & $\begin{array}{l}\text { Recovered; died of } \\
\text { acute } \\
\text { myelomonocytic } \\
\text { leukaemia two } \\
\text { years later }\end{array}$ & $\begin{array}{l}\text { Recovered; died of } \\
\text { carcinoma five } \\
\text { months later }\end{array}$ & $\begin{array}{l}\text { Recovered; died of } \\
\text { myelodysplastic } \\
\text { syndrome } \\
10 \text { months later }\end{array}$ & $\begin{array}{l}\text { Recosered; died of } \\
\text { pneumonia three } \\
\text { months later }\end{array}$ & Died of sepsis & $\begin{array}{l}\text { Recovered; died of } \\
\text { myelodysplastic } \\
\text { syndrome two } \\
\text { months later }\end{array}$ & $\begin{array}{l}\text { Recovered; alive and } \\
\text { well }\end{array}$ \\
\hline
\end{tabular}


unremarkable. When examined she was pale and had a temperature of $37 \cdot 7^{\circ} \mathrm{C}$. She had a large fluctuant mass, which was neither hot nor tender, over the left greater trochanter. $x$ Ray films showed no abnormality of either the pelvis or the left femur. The results of investigations showed that haemoglobin concentration was $62 \mathrm{~g} / \mathrm{l}$, white cell count $8 \cdot 1 \times 10^{\%} / 1$ (granulocytes $81 \%$, lymphocytes $11 \%$, monocytes $8 \%$ ), and platelet count $92 \times 10^{9} / 1$. The neutrophils were hypogranular. Bone marrow aspirate showed a normocellular marrow with trilineage dysplagia and $1 \%$ blast cells. The modified Bournemouth score was $2 .{ }^{6}$

When the mass was explored surgically an abscess cavity was found containing about $100 \mathrm{ml}$ of pus from which Staph aureus was cultured and in which abundant neutrophils were seen. She was treated with daily dressings and oral flucloxacillin and amoxicillin and made an uneventful recovery. She died at home two months after discharge from bronchopneumonia.

\section{Discussion}

Several aspects of neutrophil function have been investigated in myelodysplastic syndrome. Chemotaxis, as measured by migration through millipore filters, was found to be normal in 14 of the 17 patients that Ruutu studied. ${ }^{5}$ On the other hand, defective adhesion, phagocytosis, and bacterial killing are all commonly found. ${ }^{578}$ Given these findings, it is likely that in some patients with the myelodysplastic syndrome neutrophils can migrate to sites of infection, thus generating pus, but once there they cannot eradicate the infecting organisms.

In haematological practice it is vital to treat severely neutropenic patients who develop fever with broad spectrum antibiotics before the cause of the infection is established. Patients with the myelodysplastic syndrome often have more moderate neutropenia associated with neutrophil dysfunction. Such patients also require prompt and rigorous treatment of episodes of fever and the possibility of clinically occult pyogenic abscess should be considered.

In two of our patients (cases 4 and 7) the presence of an unexplained abscess drew attention to the possibility of the underlying syndrome, which was confirmed by examining the bone marrow. The diagnosis of this syndrome is often difficult to make because it requires high quality staining of blood and bone marrow films and an experienced haematologist. But the condition is much commoner than many have appreciated, ${ }^{3}$ and it needs to be high on the clinician's list of possible causes of unexplained abscesses, along with diabetes mellitus, alcohol abuse, and corticosteroid excess.

In our limited experience these abscesses seem best treated with the minimum of surgical intervention. Treatment by simple drainage and suitable antibiotics is recommended. Nevertheless, when patients with the myelodysplastic syndrome develop abscesses the prognosis is poor: six of our seven patients were dead within two years and four within six months.

We thank Mrs K Avery for typing the manuscript. GJM was supported by the Leukaemia Research Fund.

I Bennett JM, Catovsky D, Daniel M-T, et al. Proposals for the classification of the myelodysplastic syndromes. $B r$ F Haematol 1982;51:189-99.

2 Oscier DG. Myelodysplastic syndromes. Baillière's clinical haematology, Vol 1. 1987:289-426

3 Hamblin TJ, Oscier DG. The myelodysplastic svndrome -- a practical guide. Haematol Oncol 1987;5:19-34.

4 Mufti GM, Stevens JR, Oscier DG, Hamblin TJ, Machin D. Myelodysplastic syndromes: a scoring system of prognostic significance. $\mathrm{Br}$ f Haemato 1985;59:425-33

5 Ruutu T. Granulocyte function in the myelodysplastic syndromes. Scandinavian fournal of Haematology 1986;36(suppl 45):66-70.

6 Worsley AM, Oscier DG, Stevens JR, et al. Prognostic features of chronic myelomonocytic leukaemia: a modified Bournemouth score gives the bes prediction of survival. Br F Haematol 1988;68:17-21.

7 Boogaerts MA, Nelissen V, Roclant C, Goossens W. Blood neutrophil function in primary myelodysplastic syndromes. Br f Haematol 1983;55:217-27.

8 Martin S, Baldock SC, Ghoneim ATM, Child JA. Defective neutrophil function and microbicidal mechanisms in the myelodysplastic syndromes. $\mathcal{I}$ Clin Pathol 1983;36:1120-8.

(Accepted 16 May 1989)

\section{MATERIA NON MEDICA}

\section{Have some Madeira}

Madeira has been described as a jewel afloat in the Atlantic. It is also noted for the fortified wine that bears its name.

A volcanic island reminiscent of Corsica with just a touch of Switzerland, it has been saved from mass tourism by the fortuitous absence of good beaches. Winston Churchill found it an apt subject for painting. The British army and a fair sprinkling of British settlers played a part in its history. Motorists find the mountain roads challenging, though the car hire proprietor limited his advice to "just watch out for the big ones." By this he meant the leviathans of the road. The number of subsequent near misses certainly proved his point. Flanking a part of the main coast road sat the vendors of bread, shaded by large sun umbrellas. From insulated bins they would dispense delectable oven fresh loaves, a constant temptation to those passing by.

Every little township seemed to have a "centro de saudé," often purpose built, in a prominent position. We never had occasion to discover if these were true health centres or just substantial surgeries.

One day, deep in the island's interior, we heard the mountains echo with loudspeaker exhortations. These emanated from a closed van parked at the roadside some distance below. One word kept recurring: "Espada" (=sword). Was this an incitement to bloody insurrection? we wondered nervously. But no mountain folk appeared waving swords or any other weaponry. Back home we learnt the prosaic truth. There is an edible local fish called espada. It had been a fishmonger who had made use of a loudspeaker system to reach out to his mountain bound customers.

Walking along one of the many levada water conduits, we spotted some cactus plants clinging to near vertical rock faces. What made them seem eccentric was an unashamed enthusiasm for water. They were literally dripping with the stuff. If ever they had been members of the Society of
Proper Cacti they surely must have been expelled long ago for this misdemeanour. But back in London Kew Gardens identified them as members of a well known family of succulents that might aspire to be true cacti but will never make the grade. Equally curious for the amateur gardener proved to be the sight of dahlias and azaleas flowering together. Surely at least one of them must have forgotten its biological rhythm?

Machico is a friendly little fishing port at the eastern end. Maria, the local guide, was showing a small party of us some places of interest. The library, we noted, was funded by our late London based Nubar Gulbenkian. Then there was the school of embroidery. It was a joy to observe how keen the schoolgirls were to acquire the skills from their elders, even at the cost of their free afternoons. Inevitably someone commented on the prevalence of fair haired children.

"It was the English, the English pirates," our guide explained brightly. There was an embarrassed silence. The company was mainly English.

"Surely it could have been our army?" suggested somebody.

"No," retorted Maria firmly. "It was the English pirates." Clearly, with an incurable romantic, disputation is often unprofitable.

As we descended a steep mountain track towards Porta da Cruz a gang of woodcutters partially barred our way. They turned and motioned us to a halt. Linguistic niceties were not required. Everybody smiled. A flagon of local wine was produced, together with a cup. There would have been great offence had we declined this spontaneous gesture of good will. So partake we did, lingered a while, and then departed the best of friends.

And what of the famous Madeira cake? It exists and actually tastes twice as good when briefly reheated in a microwave oven. This valuable new knowledge might itself have justified a journey to Madeira.-K G HEYMANN, London 